\title{
Os anos 1960 e o horizonte utópico da juventude católica ${ }^{1}$
}

\section{The 1960s and the Utopian Horizon of Catholic Youth}

\author{
Wellington Teodoro da Silva \\ Daniel Rocha
}

\section{Resumo}

Este artigo trata das crenças de setores progressistas da juventude católica brasileira durante a década de 1960, especialmente as relações entre sua concepção de "fé cristã" e suas perspectivas revolucionárias no campo político e social. Na primeira seção do texto, buscamos apresentar as expectativas e expressões de fé de parte dos jovens católicos desse período. Ressaltamos a importância de se entender as concepções de cristianismo desses jovens tendo como pano de fundo o contexto político, teológico, social e cultural dos anos 1960, tanto nacional quanto internacional. Na sequência, analisamos a dimensão utópica e revolucionária da fé desses jovens. A partir de uma reflexão sobre o conceito de utopia, buscamos demonstrar como o "espírito revolucionário" e elementos da fé cristã - especialmente ligados a concepções escatológicas - se amalgamaram no horizonte de expectativas da juventude católica.

Palavras-chave: Igreja Católica e Política. Catolicismo e Revolução. Juventude Católica. Utopia.

\section{Abstract}

This article deals with the beliefs of progressive sectors of Brazilian Catholic youth during the 1960s, especially the relationship between their con-

\footnotetext{
${ }^{1}$ Este artigo apresenta resultados parciais da pesquisa "Juventude, Religião e Política" financiado pela Fundação de Amparo à Pesquisa do Estado de Minas Gerais - FAPEMIG.
} 
ception of "Christian faith" and their revolutionary perspectives in the political and social field. In the first section of the text, we seek to present the expectations and expressions of faith on the part of the young Catholics of this period. We emphasize the importance of understanding the conceptions of Christianity of these young people against the backdrop of the political, theological, social and cultural context of the 1960s, both nationally and internationally. In the following, we will analyze the utopian and revolutionary dimension of the faith of these young people. From a reflection on the concept of utopia, we seek to demonstrate how the "revolutionary spirit" and elements of the Christian faith - especially linked to eschatological conceptions - have amalgamated into the expectations horizon of Catholic youth.

Keywords: Catholic Church and Politics. Catholicism and Revolution. Catholic Youth. Utopia.

Desde os dias de João Batista até agora, o reino dos céus é tomado por esforço, e os que se esforçam se apoderam dele (Mt 11,12).

\section{Introdução}

Adécada de 1960 foi um período de grande ebulição de ideias e esperanças na esfera política, social, cultural etc. Seja nos eventos ocorridos em maio 1968 em Paris ou na efervescência dos movimentos de contracultura nos Estados Unidos, podemos dizer que os "protagonistas" dessa época de grandes rupturas eram os mesmos: os jovens. A primeira geração de nascidos após a Segunda Guerra Mundial se tornara, em diversas partes do globo terrestre, a porta-voz de uma crescente demanda por mudanças que viabilizassem um "futuro melhor" em um mundo que temia a "ausência de futuro" que poderia se tornar realidade graças à ameaça de um conflito nuclear entre soviéticos e norte-americanos. Na retórica desses jovens, o estabelecimento de uma "nova ordem" - e uma nova relação entre a humanidade e o planeta - não seria apenas uma possibilidade, mas, sim, uma necessidade. Ou o mundo estaria unido numa grande revolução ou agonizaria "unido" na destruição.

Os anos 60 foram momentos de intensas e densas rupturas e reorientações 
profundas nos diversos níveis da experiência humana em sociedade. Vale citar a política, a música, o cinema, a literatura, a poesia e a sexualidade. Elas foram reelaboradas ao mesmo tempo em que reelaboraram novos modos de sentir a realidade e de estruturar o estar humano no mundo. Num repente, um novo mundo e um novo humano eram incrivelmente possíveis. Mais que isso: estavam sendo construídos. A revolução cubana varreu como um furacão as mentalidades e era o exemplo real de que o novo estava sendo produzido sobre as velhas estruturas que pareciam desmoronar. O romantismo entre essa juventude emergiu inebriando as consciências com a esperança da vitória sobre as poderosas forças despersonalizantes das grandes estruturas modernas. ${ }^{2}$

No Brasil, setores da juventude leiga católica participaram desse amplo movimento da cultura carregado de utopias com a revolução em seu horizonte. No início da década de 1960, o país experimentava notáveis processos de organização de setores da sociedade. Muitos se orientavam no sentido da ruptura com a antiga ordem da cultura política autoritária das oligarquias. As juventudes estudantil, operária e universitária católicas; a União Nacional dos Estudantes; as Ligas Camponesas; o Movimento de Educação de Base e os sindicatos urbanos e rurais estavam entre as organizações que assumiram um papel de destaque em uma sociedade em acelerado processo de rupturas.

O catolicismo brasileiro viveu a dramaticidade desse momento particularmente denso do século XX. Entre esses jovens, o existencialismo cristão se associava a esse espírito romântico e revolucionário. Eles passaram a compreender a história como resultado do movimento dialético do drama humano na direção do Transcendente. Esse é um novo movimento religioso e político na história brasileira que formou diversos quadros políticos que se fazem presentes na política brasileira ainda nos dias de hoje. O aparelhamento simbólico, a tradição e o magistério da Igreja foram significados num cosmo de sentido de rupturas, superando a clássica evasão da história. Privilegiava-se uma dimensão da fé que possuía implicação para esta vida e não para o post mortem.

Neste texto, analisamos o universo de sentidos de jovens católicos brasileiros do início da década de 1960. Num primeiro momento, apresentamos suas expectativas e expressões de fé. Ressaltaremos a importância de se entender as concepções de cristianismo desses jovens tendo como pano de fundo o contexto político, teológico, social e cultural dos anos 1960, tanto nacional quanto internacional. Na sequência, analisaremos a dimensão utópica e re-

${ }^{2}$ RIDENTI, M. S., Ação Popular, p. 213-282. 
volucionária da fé desses jovens. A partir de uma reflexão sobre o conceito de utopia, demonstramos como o "espírito revolucionário" e elementos da fé cristã - especialmente ligados a concepções escatológicas - se amalgamaram no horizonte de expectativas da juventude católica. Sobre o método, vale dizer que seguimos Le Goff quando afirma que o historiador transforma em documento tudo o que lhe possa fazer o passado se desvelar. ${ }^{3}$ Trans-formamos o escrito dos intelectuais daquele momento em nossos documentos em segundo os rigores de uma história intelectual. ${ }^{4}$

\section{Fé e práxis em tempos de ruptura}

Uma compreensão adequada das esperanças de setores progressistas da juventude católica brasileira durante a década de 1960 passa, necessariamente, pela contextualização de suas crenças e práticas. As interpretações e apropriações "revolucionárias" da fé cristã são ininteligíveis se dissociadas de seu contexto político, social e cultural e das experiências e expectativas dos grupos que as confessavam. ${ }^{5}$ As esperanças de um futuro redentor devem ser interpretadas na dimensão do "futuro presente", o futuro cuja proximidade ou distância tem sua repercussão no presente na forma de variadas expectativas. E tais expectativas do futuro, muitas vezes, têm o enorme poder de transformar o presente - e, em não menos vezes, de dar novos significados ao passado. Além disso, uma nova percepção sobre o presente pode ser responsável por uma transformação em relação ao futuro esperado.

Certos momentos da história foram marcados pela convicção de estar-se às portas da irrupção de um "novo tempo". Tal convicção torna-se uma espécie de lente através da qual as pessoas interpretam o passado, dão significado ao presente e criam expectativas em relação ao futuro. Por exemplo, os homens da Renascença italiana, nos últimos anos do século XV, entendendo-se

\footnotetext{
${ }^{3}$ LE GOFF, J., Documento/monumento, p. 525 - 541.

${ }^{4}$ Sobre as perspectivas e questões metodológicas relativas à história intelectual, ver: SIRINELLI, J., Os intelectuais; KELLEY, D. R., Horizons of intellectual history.

${ }^{5}$ Aqui fazemos uso das noções de "espaço de experiência" e "horizonte de expectativa" do historiador alemão Reinhart Koselleck. O "espaço de experiência" seria o "passado-presente", o conhecimento sobre o passado que existe no presente preservado através da memória, dos vestígios, das relíquias, dos documentos históricos etc. O "horizonte de expectativa", por sua vez, seria o "futuro-presente": esperanças, dúvidas e ansiedades projetadas em relação ao futuro a partir do presente. Sobre tal discussão, ver: KOSELLECK, R., Espaço de experiência e Horizonte de expectativa, p. 305-327.
} 
como inauguradores de uma nova forma de pensar e de entender o mundo, estabeleceram uma nova leitura sobre o passado e buscaram legitimar suas atividades "mundanas" do presente a partir de um retorno aos valores da "era de ouro" da Antiguidade clássica. E, ao mesmo tempo em que conectavam a sua época ao "glorioso" passado clássico que abriria as portas para um futuro benfazejo para a humanidade, eles criaram uma nova interpretação sobre o passado recente que havia deixado de lado tais valores: teria sido uma "Idade das Trevas". Já na França do final do século XVIII, o espírito revolucionário ensejava a possibilidade de uma "nova criação", de recomeçar o mundo em novos termos, dar início a um novo mundo em um novo tempo. Tal convicção, inclusive, levou os revolucionários a "zerar" a história e a inaugurar um recomeço para a história dos homens com a criação do calendário revolucionário francês pela Convenção Nacional de 1792.

A década de 1960 foi um desses momentos de rupturas que abria possibilidades de inaugurar uma nova era na história humana. Se, por um lado, as tensões da Guerra Fria e da corrida armamentista faziam com que a ameaça de uma catástrofe global estivesse sempre à espreita, uma série de transformações que ocorriam ao redor do mundo insuflavam esperança de um rompimento com as estruturas sociais perversas. As lutas contra a segregação racial, contra regimes autoritários, contra a exploração econômica, contra a opressão sofrida pelas mulheres e minorias ganharam uma importância e destaque sem precedentes. As igrejas cristãs e a reflexão teológica não permaneceram incólumes a esse contexto. Tornara-se imperativo que a fé cristã entrasse em diálogo com o "espírito da época". A Igreja Católica abriu-se para a modernidade por meio da realização do Concílio Ecumênico Vaticano II. Importantes teólogos escreviam sobre esperança, justiça social, libertação e revolução. Em The Secular City, publicado originalmente em 1965, o teólogo norte-americano Harvey Cox afirmava que:

O ponto de partida para qualquer teologia da igreja hoje deve ser uma teologia da mudança social. A igreja, antes de tudo, uma comunidade que responde, um povo cuja tarefa é discernir a ação de Deus no mundo e participar de Sua obra. A ação divina ocorre através do que os teólogos chamam, algumas vezes, de "eventos históricos", mas que deveria ser chamado de "mudança social". Isso significa que a igreja deve responder constantemente à mudança social, mas isso é apenas o problema. Nossas doutrinas sobre a igreja chegaram até nós do desgastado período da Cristandade clássica e estão infectadas com a ideologia da preservação 
e da permanência. Tais doutrinas são quase inteiramente orientadas pelo passado, derivando sua autoridade de um ou outro período clássico, de uma suposta semelhança com alguma forma anterior de vida da igreja ou de uma teoria de continuidade histórica. Mas isso não mais se sustentará. Uma igreja cuja vida é definida e moldada pelo que Deus está fazendo agora no mundo não pode estar aprisionada a tais especificações antiquadas. A igreja deve permitir-se ser quebrada e remodelada continuamente pela ação contínua de Deus; daí a necessidade de uma teologia da mudança social. $^{6}$

Setores da juventude católica brasileira no início da década de 1960 estavam em sintonia com essas novas perspectivas sobre o "ser cristão" no mundo. Compreendia-se que as origens bíblicas da tradição cristã e a história do cristianismo ensinavam que o movimento para a eternidade do Reino incluía a realização da comunidade fraterna na terra. A salvação seria consumada por um Deus histórico e eticamente envolvido com os destinos de sua criação. A transcendência exigiria o cuidado com o mundo e o envolvimento com seus problemas.

No caso brasileiro, vários jovens católicos advogavam a necessidade de confrontar as nefastas estruturas estabelecidas historicamente pelos arranjos oligárquicos. Esse movimento teve início a partir da década de 1940 fazendo esse catolicismo se distanciar da reação católica das décadas de 1920 e 1930. Entretanto, ele ganha em relevância e complexidade entre fins da década de 1950 e primeira metade da década de 1960. No seio desse movimento, destacavam-se duas posições: os proponentes de uma revolução que superasse o capitalismo; e os reformistas que propunham superar o atraso econômico, político e social por meio das reformas de base que aconteceriam pelas vias

\footnotetext{
${ }^{6}$ Tradução nossa. No original: "The starting point for any theology of the church today must be a theology of social change. The church is first of all a responding community, a people whose task it is to discern the action of God in the world and to join in His work. The action of God occurs through what theologians have sometimes called "historical events" but what might better be termed "social change." This means that the church must respond constantly to social change, but this is just the trouble. Our doctrines of the church have come to us from the frayed-out period of classical Christendom and are infected with the ideology of preservation and permanence. They are almost entirely past oriented, deriving their authority from one or another classical period, from an alleged resemblance to some earlier form of church life, or from a theory of historical continuity. But this will no longer do. A church whose life is defined and shaped by what God is now doing in the world cannot be imprisoned in such antiquated specifications. It must allow itself to be broken and reshaped continuously by God's continuous action; hence the need for a theology of social change". COX, H., The secular city, p. 125.
} 
propriamente políticas da democracia parlamentar. Esses dois lugares não se constituíam em tipos quimicamente puros. Havia trânsito de pessoas e de ideias entre ambos. De uma maneira geral, a revolução era compreendida como necessidade histórica, caso a via política dada fosse incapaz de responder às demandas apresentadas.

Em 1962, o jovem militante católico Herbert de Souza relatava que sua geração vivenciava uma atitude fundamental de adesão ao drama do homem. A redenção não se apresentava de maneira dualista. Ela envolvia o humano como um todo indissociável desde sua condição histórica. A "perspectiva aristocrática e classista da salvação" foi recusada a favor da "perspectiva universal do cristianismo: todos os homens e o homem todo são objetos do amor e da salvação". ${ }^{7}$ Dessa forma, a concepção de cristianismo dessa juventude recusava qualquer perspectiva que dividisse os humanos em senhores e escravos ou entre exploradores e explorados. Situações sociais em que alguns possuíam direitos universais enquanto outros eram titulares restritos de direitos. Betinho considerava que aquela geração era o prolongamento de outras gerações que remontavam à geração inicial do Novo Testamento. Esses jovens assentiam que o cristão era portador de uma mensagem universal e concreta de amor que nada tinha a ver com abstrações sem impactos na emancipação humana na justiça. Eles se opunham a tudo que considerassem como farisaísmo, falsa profecia, individualismo e materialismo.

A condenação às formas assumidas pelo capitalismo passou a ser uma tônica no discurso desses jovens. A consciência em relação às distorções e injustiças sociais geradas por esse sistema fez com que vários jovens e alguns religiosos passassem do ativismo assistencialista para um discurso mais crítico às "estruturas pecaminosas" da sociedade capitalista. Ela seria materialista e estabeleceria a desigualdade de oportunidade desde o início da vida das pessoas. Além disso, ele forçaria a competição, promoveria a economia do lucro contra a economia da necessidade. Dessa forma, asseguravam que a coerência cristã impunha a condenação do capitalismo.

A fé em Cristo produziu nesses jovens o apelo à primeira revolução, a saber: pessoal e espiritual. Ela se traduzia na superação pessoal da negação do amor, do comodismo e da indiferença pela sorte da humanidade. Essa geração recebeu com grande impacto o livro A descoberta do Outro, de Gustavo Corção. Sobre essa descoberta, Betinho escreveu: "A descoberta do outro, a

${ }^{7}$ CARDONNEL, T.; VAZ, H.; SOUZA, H. J., Cristianismo Hoje, p. 100. 
superação da subjetividade que isola (...) enfim, a superação em nós de velhas e deformadas visões de um cristianismo místico, supersticioso e formal". ${ }^{8}$

A temática da revolução surgiu entre esses jovens católicos a partir da questão social. O marco reconhecido como inaugurador dessa questão foi a publicação da encíclica Rerum Novarum, em 1891, pelo papa Leão XIII. No Brasil, ela não surgiu como um problema teórico que foi se colocando na agenda dos movimentos eclesiais. A teoria foi sendo formulada na medida em que os problemas se apresentavam no teatro da militância. Ela demandava sentidos religiosos e respostas teológicas em um ambiente que demonstrou, por exemplo, que os comunistas produziam discursos plausíveis sobre as causas da miséria. Reconhecer que o comunista tinha razão em muitas de suas asserções era escandaloso num momento em que eles foram maximamente demonizados.

Esses jovens católicos compreendiam que a revolução era mais propriamente cristã que marxista. A encarnação do Filho de Deus na condição humana teria significado o grande momento revolucionário da história. Esse foi o grande ato pelo qual Deus participa da história elevando o humano à sua dignidade absoluta. Marx teria tomado o humano muito tarde, após a criação, e o soltado muito cedo, antes da redenção. Ser revolucionário significaria participar do processo criativo e salvífico de Deus. É o modo máximo de ação humana na história com vistas ao final dos tempos. Desse modo, a revolução cristã é mais complexa e densa que a compreensão marxista por sua ausência de transcendência e dialética "preguiçosa" por esgotar-se na história. O materialismo marxista também se apresentava numa perspectiva redentora que, secularizada, ganhou o nome de emancipação. O horizonte utópico dele não se realizaria no transcendente, mas no imanente histórico.

Os setores progressistas da juventude católica acreditavam que o cristianismo havia preparado a pedagogia da revolução e da modernidade. Até meados da década de 1960, eles recusavam a ideia de que a defesa da revolução conduziria, necessariamente, ao marxismo. Essa compreensão não significava que os marxistas não pudessem ser interlocutores relevantes. $\mathrm{O}$ marxismo estaria correto em suas asserções sobre as causas das misérias e da exploração humana. Contudo, equivocava-se ao propor uma visão anêmica de superação da realidade encerrada no imanente. De fato, a fé cristã seria o "lugar" da máxima superação possível para o ser humano: o triunfo da ressurreição sobre a morte.

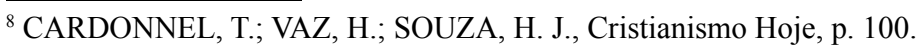


Ao longo dos séculos, o cristianismo preparou um ambiente cultural que produziu e foi capaz de comportar no imaginário uma radical superação de estruturas econômicas, sociais e históricas na direção de outras formas que suplantassem em tudo as anteriores: morte e ressurreição de estruturas da história.

A relação da esquerda católica com os comunistas acontecia de maneira distinta dos setores reacionários do catolicismo. Segundo o frade dominicano Thomas Cardonnel (1962), a poderosa propaganda reacionária localizava geograficamente o "demônio": União Soviética e Cuba, por exemplo. Essa consciência condenatória seria anticristã, porque operaria na cultura do anátema em tempos em que o mundo havia produzido condições de diálogo. Além disso, esse anticomunismo acabava por defender o capitalismo que também era combatido pelo magistério papal. Tanto o sistema capitalista quanto o comunista eram recusados por serem igualmente materialistas. Ambos não colocavam a pessoa humana no centro estruturante de seu funcionamento. Em um era o mercado e o lucro que sufocava o humano. No outro, era o trabalho e uma certa ideia de história excessivamente estrutural. A tecnocracia como critério definitivo era temida em ambos os sistemas; recusava-se o domínio desumanizante da tecnocracia mundial. E, ainda, ambos comungavam o gosto pelo poder. Cultivavam uma cultura relacional de agir sobre o outro ao invés de agir junto dele. A força e o poder não deveriam ser critérios de ação entre os homens.

A existência de povos subdesenvolvidos denunciava o vazio das ideologias. A existência de miseráveis era o critério definitivo para a condenação do mundo constituído. O capitalismo e o socialismo existentes não ofereciam meios práticos de as pessoas se humanizarem, viverem a realidade existencial profunda na sociabilidade, politicidade e espiritualidade. Dessa forma, filiarse acriticamente a um ou outro bloco da Guerra Fria era compreendido como se associar a estratégias de poder globais que recusavam a pessoalidade do humano. Portanto, eram infernais segundo critérios evangélicos. Um dos riscos identificados era a existência de uma humanidade tecnicamente avançada e humanamente infantilizada.

Cardonnel asseverou que Deus não é tão mentiroso, tão falso como a paz social construída a partir de consentimentos com uma justiça antinatural. Citando Mounier, afirmava a existência de uma desordem estabelecida e violentamente produtora de injustiças. Por sua vez, a luta de classes não era uma elaboração dos marxistas. Era um dado do real histórico e econômico que se impunha de maneira concreta e objetiva diante das consciências e 
inteligências. Ela expressava as condições da falsa paz. Os trabalhadores urbanos e rurais não tinham a iniciativa dessa luta. Ela era imposta pelos detentores da propriedade do capital e dos meios de produção.

A solução do problema para esses católicos não estava na mera substituição de uma classe por outra no poder. Socialismo e capitalismo, um diante do outro, assemelhavam-se à fotografia e ao seu negativo. São opostos nas cores, mas coincidentes na estrutura. A ditadura do proletariado era ilusória e o partido único, uma ditadura impensável. De ser assim, Cardonnel propunha que não se deveria meramente mudar a titularidade do poder, mas a natureza mesma do poder. Ele não deveria ser de dominação, mas de participação unânime. A sociedade deveria ser capaz de mudar a lógica das relações humanas de opressão pela cooperação, pela justiça e pela amizade mútua. $\mathrm{O}$ cristão deveria evitar a fuga abstrata que se constituía no idealismo e espiritualismo. Em sua condição de religião histórica, o cristianismo se corrompe quando comporta a evasão da história.

Esses jovens cristãos viam-se diante do imperativo de construir relações sociais e econômicas que permitissem ao povo faminto sair de sua condição de vida meramente orgânica para a vida consciente. Ultrapassar a busca pela sobrevivência orgânica para o salto para a vida capaz de se autoproduzir cultural e intelectualmente. As comunidades humanas deveriam emergir, revolucionariamente, das realidades dominadas pelos determinismos econômicos do capitalismo liberal e do marxismo.

A adesão ao fato histórico Jesus de Nazaré produzia o movimento dialético de torná-lo contemporâneo à década 1960. Em Cristo, o princípio de toda separação e a própria morte são destruídas por Deus. Dessa forma, o pecado por excelência do cristão seria resignar-se ao fato de ser mortal e a recusa à comunitariedade. A partir da Ressurreição de Cristo, o cristão deveria vencer todas as formas de morte expressas nas "diversas condições de escravidão dos homens, dos proletários, dos subproletários, a prostituição, a submissão no luxo e na riqueza, os diversos tipos de colonialismo econômico e político". ${ }^{9}$ A revolução do cristianismo era compreendida e proposta por esses jovens como evento integral que inauguraria novas estruturas sociais e um novo ser humano capaz de ultrapassar a vida possuída para a vida partilhada. A conscientização era o ato por si só suficiente para provocar essas transformações. Reputar a condição de alienado era uma das grandes

${ }_{9}^{9}$ CARDONNEL, T.; VAZ, H.; SOUZA, H. J., Cristianismo Hoje, p. 28. 
ofensas nos debates do período. Para além das reduções materialistas da revolução, Jesus Cristo era tratado como único fundamento de uma transformação radical da história para que não existam mais, "como diz São Paulo, 'nem judeu nem grego, nem escravo nem homem livre, mas que todos sejamos um em Cristo Jesus"." ${ }^{10}$

\section{O horizonte utópico}

Não sendo acessível ao conhecimento humano, pois dele nada podemos afirmar com plena certeza, o futuro é objeto apenas de expectativa. Entre expectativas luminosas e expectativas sombrias, entre sonhos e pesadelos, o futuro pode tanto aterrorizar quanto encher de esperança os espíritos dos que habitam o fugidio presente. Apesar de toda a impossibilidade de ser "experimentado" de antemão, o futuro engravida o presente com suas luzes e/ou sombras e reestrutura pensamentos, projetos, visões de mundo etc. A presença da expectativa do futuro no presente dos indivíduos faz com que, ao invés de serem esvaziados de vida e de sentido pelo passar do tempo, eles busquem dar significado ao tempo na tentativa de encontrar um propósito final para a própria existência e para a existência da humanidade como um todo.

Nunca podendo ser "experimentado" de antemão, as expectativas em relação ao futuro são moldadas pelas experiências do presente. Como dissemos anteriormente, a década de 1960 aparentava ser, especialmente para a juventude, o início de um novo tempo em ruptura com as velhas estruturas de um passado decadente. Jovens negros do sul dos Estados Unidos compartilhavam o sonho do reverendo Martin Luther King Jr. de uma sociedade onde negros e brancos desfrutassem dos mesmos direitos e vivessem como irmãos. Na contracultura, especialmente entre os hippies, as críticas ao materialismo e à hipocrisia da sociedade estabelecida eram embaladas por"intensas expectativas milenaristas, encarando a sociedade atual como o último estágio de degradação antes do advento de uma nova era", ${ }^{11}$ a aguardada Era de Aquário. Enquanto uma parte da juventude focava seu discurso na prioridade do "fazer amor" sobre o "fazer a guerra", outros criam ser necessário trazer o futuro almejado para o presente através de uma revolução armada. A revolução cubana de 1959 colocou

${ }^{10}$ CARDONNEL, T.; VAZ, H.; SOUZA, H. J., Cristianismo Hoje, p. 30.

${ }^{11}$ BELLAH, R. N., A nova consciência religiosa e a crise na modernidade, p. 29. 
"lenha na fogueira" das esperanças da intelectualidade latino-americana de esquerda. O Caribe tornou-se o epicentro de um movimento de expansão dos ideais socialistas e de resistência ao imperialismo ocidental, em especial norte-americano. O presente revolucionário transformou-se em lente para se reinterpretar o passado e vislumbrar o futuro: "Cuba se tornou algo como o futuro no presente dos demais países caribenhos e latino-americanos". ${ }^{12} \mathrm{Cuba}$ transformara-se na "musa inspiradora" para todos os sonhos de construção de uma América Latina livre, justa e revolucionária.

Aquilo que se espera do futuro, já tem suas sementes plantadas no presente. Da mesma forma, a expectativa em relação ao que há de vir possui influência decisiva sobre os pensamentos e atitudes do presente. Nos termos de Koselleck, "não há expectativa sem experiência" e "não há experiência sem expectativa". ${ }^{13}$ Quando falamos de um sentimento utópico presente no pensamento e nos discursos desses setores progressistas da juventude católica da década de 1960, não nos referimos a projetos sem nenhuma conexão com a realidade de sua época. Esses jovens associaram o cristianismo à revolução e aos modos do pensamento utópico. Essa perspectiva recusa uma dada realidade histórica, ao mesmo tempo em que assegura a possibilidade de sua superação. Esses jovens formularam a utopia como o bom-lugar, segundo Moses Finley (1989). Esse autor alerta para a ampla, complexa e confusa gama semântica ou, como ele mesmo chama, espectro de significados, da palavra utopia, desde que foi utilizada por Thomas More. O próprio termo apresenta possibilidades de significados que determinam sentidos diversos. Sobre essa palavra, Finley afirma que:

Via de regra não se dá a devida atenção. A letra "u" inicial corresponde à letra grega ou ("nenhum", "não"); portanto utopia é "nenhum lugar". Mas, se usarmos um pouco de imaginação, o "u" também pode corresponder ao prefixo grego eu ("bom", "bem"), então termos "lugar bom", "lugar ideal". Essa alternativa não é totalmente fantasiosa, como provam dois versos de "Meter of IV Verses in the Utopian Tongue" apenso à obra de More, que, segundo a versão inglesa do século XVI, dizem: "Portanto, não Utopia, porém, mais corretamente / Meu nome é Eutopia: lugar de felicidade". ${ }^{14}$

\footnotetext{
${ }^{12}$ RAMOS, D. V., A invenção do Caribe como contracultura e a revolução cubana, p. 461.

${ }^{13}$ KOSELLECK, R., Futuro passado, p. 37.

${ }^{14}$ FINLEY, M., Usos e abusos da história, p. 193.
} 
Utopia, portanto, pode tanto significar um não-lugar quanto um bomlugar. No primeiro sentido, a sua determinação é negativa e se revela como uma formulação alienante da consciência. Ela recusa os dados e os imperativos concretos e subsiste na troca do real pelo imaginado/desejado sem ação objetiva no processo histórico. O segundo sentido apresenta-se de maneira positiva. É o bom lugar possível de ser alcançado pela ação humana. A utopia só pode ser utopia enquanto projeto realizável no tempo e na história. Ela cumpre a tarefa de formular o horizonte que orienta o caminho a seguir. Não é lugar de chegada. É antes de tudo uma força que anima a práxis. É um constructo ideal no nível da mentalidade. Em sendo assim, situa-se no lugar do possível e do inalcançável ao mesmo tempo e sem contradição. Esses tensos e contraditórios lugares são bem elaborados no ambiente de sentidos do cristianismo que deixam vagas para essa síntese no momento escatológico.

O cristianismo e a utopia afeiçoam-se de maneira especial. Ele vive o impermanente do tempo histórico apontando para o momento último: a consumação. É o meta-lugar. A-histórico. Inefável. A descrição é densa nos movimentos milenaristas. Neles, observamos como a esperança e a utopia constroem-se de maneira privilegiada a partir do oprimido. A primeira oferecendo um suporte, uma reserva de fé na plausibilidade da segunda. A esperança suscitada pelo Milênio engravidou o espírito de muitos. Os milenarismos tiraram o foco escatológico das questões relativas à salvação individual e à vida eterna e o colocaram sobre a vida terrena - com todas as suas dificuldades, alegrias e contradições. A esperança do Milênio, além de trazer os impactos das crenças escatológicas para as expectativas do dia a dia do crente, também se tornou um catalisador de anseios coletivos, inspirando o surgimento de vários movimentos de fundo milenarista.

Dessa forma, esses jovens compreendem que o humano ultrapassa o tempo do calendário na direção da realidade última, universal e sagrada, posterior ao próprio tempo. Portanto, não produziam uma religião da evasão do mundo, mas de sua superação escatológica. Suas categorias de sentido ultrapassam a história. O mundo não era negado num simplismo idealista ou "ultra-espiritualizado". Efetivamente, recusava-se uma dada ordem no mundo que agredia a dignidade do humano criado à imagem de Deus. Ele não era o vale de lágrima que deveria ser suportado na esperança redentora, mas deveria ser revolucionado como ato de participação da redenção que principia na história. E revolução implica rompimento com as estruturas malignas do "presente século". 
Podemos ver um paralelo entre essa dinâmica social das reformulações escatológicas e a discussão de Karl Mannheim (1976) sobre as noções de ideologia e utopia. Para Mannheim, tanto a ideologia quanto a utopia partem de ideias que transcendem o contexto social em que se encontram e apontam para uma nova forma de sociedade. Porém, enquanto as ideologias "jamais conseguem de fato a realização de seus conteúdos pretendidos", pois "seus significados, quando incorporados efetivamente à prática são, na maior parte dos casos, deformados", as utopias "conseguem, através da contra-atividade, transformar a realidade histórica existente em outra realidade, mais de acordo com suas próprias concepções". ${ }^{15}$ Depreende-se, então, que as posturas utópica ou ideológica estão diretamente ligadas à questão da ordem de coisas existente. Em confronto com a ordem vigente, a utopia, necessariamente, precisa romper com ela para instalar uma nova ordem. A ideologia, por outro lado, parece abrir uma espécie de "diálogo" e acaba por incorporar vários valores do status quo, diferenciando-se das utopias ao se tornarem aceitáveis e adequadas à visão de mundo reinante. ${ }^{16}$

A utopia cristã elabora a dinâmica passado-presente-futuro. O passado é o tempo arquetípico das referências fundamentais. O tempo-exemplo; denso; carregado de significados. Não é um passado idealizado que se espera reproduzir no presente, como pensa o pensamento reacionário. O presente é o tempo da experiência objetiva de vida no qual se atualiza memória e a reprodução arquetípica do passado. Memória ritualmente mantida na qual se experimenta o futuro nas antecipações sacramentais do Reino. Vive-se uma dada realidade de maneira antecipada, portanto, precária. O presente está sempre sob protesto por situar-se entre o tempo-exemplo e o tempo-utópico. Não possui a mesma densidade mítica do passado e está distante das promessas do futuro. Contudo, é o tempo que sustenta objetivamente os sujeitos e seus sonhos acordados. O futuro, por sua vez, é o tempo das realizações. É

\footnotetext{
${ }^{15}$ MANNHEIM, K., Ideologia e utopia, p. 218-219.

${ }^{16}$ Embora certas ideias utópicas tenham sido reprimidas com violência ao longo da história, algumas outras acabaram sendo controladas, para não dizer cooptadas, pelos representantes de uma determinada ordem. Alguns ideais transcendentes e com potencial utópico/revolucionário, ao se tornarem aceitáveis para o status quo, tornaram-se impotentes e suas ideias ficaram relegadas ao "mundo espiritual", sem aplicabilidade palpável nas questões colocadas pela realidade histórica. Acabaram por se adequar à cosmovisão da sociedade e do tempo onde se encontravam. Nesse sentido, ganharam um caráter não revolucionário e, de acordo com Max Weber (1982, p. 385), se apoiavam no "voltar a outra face" e no "não resistir ao mal" da "solução antipolítica radical do místico". Negando, assim, o "estigma da violência de que nenhuma ação política pode fugir".
} 
o bom lugar. É o tempo do milênio e do pós-milênio, quando a própria ideia de futuro será superada porque o próprio tempo será suprimido. Também é tempo denso, uma vez que é pleno das realizações das esperanças. A utopia seria a síntese aberta desses três tempos.

O cristianismo afeiçoa-se ao pensamento utópico por ser o modo de experienciar o constante devir da história e do tempo na consciência enquanto aguarda a sua consumação. O pensamento utópico orientando para o bom-lugar indica o sentido da ação. Ele gera uma dinâmica, uma fonte de práxis, em um humano comprometido com o movimento sempre continuado da mudança histórica. Ao invés de produzir alienação, ele assegura a consciência da impermanência/trânsito da história e de tudo que é histórico. O risco desse pensamento é tentar presentificar o futuro. Ao fazer isso ele se transforma em a-histórico e violento como no caso dos vários exemplos que podemos encontrar no socialismo real. A formulação do horizonte utópico deixa vaga para a continuada presentificação do futuro. Em nossa consciência, o futuro é móvel e cumpre a tarefa de qualificar as condições do presente. O passado cumpre tarefa diversa. Por sua vez, a violência do reacionário é daquele que sempre busca a evasão da história. O passado idealizado imobiliza a ação criadora porque não oferece um lugar histórico para se atingir; teme o futuro. Apenas no nível dos ritos a atualização do passado é possível, nunca no nível da política e das realidades societárias objetivamente dadas.

É porque o homem constrói utopias - e não só as imagina - que ele se torna capaz de julgar o imediato e o factual, seja em referência ao passado pela saudade, pela lembrança, pela recordação de uma idade de ouro; seja em referência ao futuro pela esperança de um paraíso num comportamento que vai transformar o presente. ${ }^{17}$

As primeiras utopias foram medicinais. A luta contra o destino começa pela saúde do corpo. O desejo de assegurar a vida é o núcleo denso de toda a utopia. A ação é o exercício de superação de necessidades objetivas e, ao mesmo tempo, ato de fé na capacidade de superar o meio ambiente hostil, indiferente às necessidades humanas. O pensamento utópico está sempre em defasagem com o presente, transcendendo-o como dialética antecipadora. Dessa forma, não existe utopia "porque o homem se crê perfeito, ou porque tem a lembrança de uma perfeição anterior, mas, ao

${ }^{17}$ FURTER, P., Dialética da esperança, p. 127. 
contrário, porque se descobre imperfeito e quer ultrapassar este estado até atingir uma perfeição absoluta". ${ }^{18}$

A utopia deve ser apreciada pelo seu grau de negação da realidade e pela sua capacidade de despertar o entusiasmo para uma prática de mudança de uma conjuntura dada. De ser assim, ela desvela uma dialética antecipadora compondo o substrato da ideia transformadora da realidade. É o motivador daquilo que Paul Tillich chamou de princípio protestante. Em se tratando do ambiente religioso cristão, a asserção de Tillich sobre o princípio protestante se apresenta de maneira esclarecedora: "expressão teológica da verdadeira relação entre o incondicional e o condicional ou, religiosamente falando, entre Deus e o ser humano". ${ }^{19}$ Ela envolve sempre um julgamento da condição humana oferecendo um lugar na consciência onde a realidade futura é experienciada antecipadamente.

Tanto no horizonte político quanto no religioso, a antecipação não é empírica. Contudo, a pessoa consegue fazer juízo de valor sobre a realidade antecipada no nível da imaginação. Ainda que precariamente, a realidade antecipada é qualificada como boa ou má. Essa operação oferece sentido e ânimo para a práxis. O sentimento produzido por uma situação ideal de justiça anima a ação transformadora. Dessa forma, os famintos mais que os saciados são responsáveis pelas transformações da história. A antecipação possui capacidade de produzir significado para a própria existência, possibilitando que determinada classe ou determinado grupo social produza sentido na história e da história. A construção de sentido elaborada numa realidade social precária e de opressão é feita numa tensa ação criativa que leva o presente a ser superado. É o potencial de transformação social dos marginais.

A esperança, por sua vez, sustenta a utopia. Ela não é um mero esperar passivo. É a espera-ativa que torna alcançável as formulações da consciência com vistas às superações pessoais, sociais, políticas. $\mathrm{O}$ fenômeno da esperança se associa à fome. A consciência humana que sente e compreende a interpelação, o significado e o risco para a vida, motiva a ação para construir as condições para a sua saciedade. Para além de ser um fato sócio, econômico e cultural universal, ela carrega significações profundas sobre a condição humana, os sonhos individuais e coletivos e a própria condição temporal.

\footnotetext{
${ }^{18}$ FURTER, P., Dialética da esperança, p. 152.

${ }^{19}$ TILLICH, P., A era protestante, p. 183.
} 
A fome possui limiares, como qualquer outro sentimento. Ela pode levar o humano a sair de si, provocando questões e ações radicais como a revolucionária. Em sendo assim, obriga-o a traçar estratégias eficazes de abertura ao meio, ao outro e ao transcendente - ainda que um transcendente na imanência da história, no caso do marxismo. Por outro lado, numa situação de inanição total que impossibilite qualquer ação por motivos de ordem biológica e de consciência devorada pela carência completa. Nesse caso, segundo Furter, ela se torna onipresente ao ponto de enlouquecer. No outro extremo há a satisfação total que apaga a consciência da fome. Nesse lugar, a atrofia da inteligência acontece por força da ausência da necessidade de a criatividade operar, imbecilizando-se. Esta vida se torna vegetativa e parasitária, incapaz de criar o belo e o bom. Furter termina por dizer que a fome assim como a dor é fundamental para a existência humana. A grande questão é determinar seus limites. $^{20}$

Aquele que tem fome coloca-se numa situação de marginalidade contra a qual oferece combate. Ele compreende que dificuldades de natureza econômica e social dificultam-lhe a superação da condição de famintos. Ele se compreende como a antítese dessa realidade que não o abriga em seus centros de satisfação material, intelectual e espiritual. O sentimento da fome e a consciência de ser antítese formulam a utopia revolucionária. $\mathrm{O}$ desejo é outro elemento constitutivo da esperança. Para entender este elemento é necessário que entendamos a diversidade de conotações da fome. Esta não existe apenas na dimensão do biológico, das necessidades do corpo. "Existem também fomes afetivas, sentimental, erótica, intelectual. O conjunto destas fomes pode ser caracterizado como o desejo, sendo a vontade humana de ir além que faz crescer, desenvolver e aumentar as dimensões do homem". ${ }^{21}$

Essa diversidade de conotações para a fome encontra na religião cristã reconhecimento e legitimidade: "Infelizes, vós que estais saciados agora: tereis fome" (Lc 6,25). "Felizes os que têm fome e sede da Justiça: eles serão saciados" (Mt 5,6). Essas referências evangélicas foram interpretadas pelos católicos como sendo a própria historicidade humana assumida inteiramente, principalmente nas relações sociais de desigualdade, por Jesus Cristo.

Furter, seguindo no pensamento de Bloch, propõe ainda outros "fatos elementares em que se enraíza a esperança. Trata-se dos sonhos acordados

\footnotetext{
${ }^{20}$ FURTER, P., Dialética da esperança, p. 81.

${ }^{21}$ FURTER, P., Dialética da esperança, p. 82.
} 
(...)". ${ }^{22} \mathrm{O}$ sonho acordado é repleto de sentido. Nele se gesta o porvir. Manifesta a verdadeira fome dos planos futuros. Antecipa. Oferece o norte a ser alcançado pela ação objetiva dos indivíduos em busca de superação do presente, cuja onipotência é negada justamente pelo fato destes sujeitos históricos sonharem acordados.

Afirmamos que o lugar do revolucionário é de extrema densidade intelectual, de dinâmica da inteligência. Assim o é porque ele situa-se no lugar social dos pobres, dos famintos. Esse lugar social possui muita densidade de pensamento de sujeitos que traçam continuadas estratégias. E estas se referem à busca pela sobrevivência. Para os empobrecidos, o real não é apenas um conjunto de fatos que oprimem, ele é objeto de análise, de descoberta, de cuidadosa leitura. Os empobrecidos fazem uma profunda e eficaz hermenêutica da realidade. E isso é um imperativo, pois, mais que as demais pessoas, dela depende a sua vida. As experiências cotidianas das pequenas fomes e desejos que conseguem saciedade são pedagógicas para dar plausibilidade para as saciedades das grandes fomes e desejos por outras relações sociais, políticas e econômicas.

\section{Conclusão}

No século XX, a esperança da emancipação humana foi depositada na revolução. Ela fora compreendida como o único processo capaz de superar as pesadas forças estruturais inaugurando outras que permitissem ao ser humano viver a liberdade e a igualdade. Esses dois sonhos foram as principais utopias orientadoras das ações humanas. Contudo, não se efetivaram no real histórico.

Os católicos tratados neste artigo propunham o ato revolucionário como exigência do próprio cristianismo, inaugurador da matriz de sentidos que preparou a cultura para o desenvolvimento da revolução. Essa experiência estava voltada para o futuro. Ao conseguirem fazer o cristianismo comportar o ideário revolucionário na segunda metade do século XX, ele o envolve em uma trama de sentido e significado utópico próprio de quem acredita que a história não consumirá a humanidade. É ela que será escatologicamente consumida no Absoluto. O núcleo da utopia, bom-lugar, e da revolução foi traduzido por esses fiéis como a busca pela terra sem males. Ambas manifestam o desejo de salvação humana.

${ }^{22}$ FURTER, P., Dialética da esperança, p. 83. 
Para esses cristãos a revolução era uma ideia-força. Em sendo assim, ela se associa ao pensamento utópico. No sentido do bom-lugar, a utopia se apresenta como uma força dinâmica que é capaz de tornar a ação um ato irresistível. O desejo da terra sem males, onde corre leite e mel, é uma das antiquíssimas utopias religiosas da humanidade. Esse desejo foi traduzido na década de 1960 dentro do espírito da década que pareceu adensar no nível das mentalidades os processos de trânsitos e rupturas.

Apesar de defendermos a necessidade de não se "descolar" as crenças dessa juventude católica progressista de seu contexto histórico, como se dele ela fosse independente, também não podemos cair em um reducionismo que enxerga tais crenças apenas como narrativas com fins totalmente pragmáticos - a utilização de uma retórica religiosa apenas para legitimar um determinado posicionamento político. É necessário compreender o sentido que as questões políticas e sociais têm sob o ponto de vista da fé. As crenças religiosas produzem um saber sobre a realidade que se funda em premissas como quaisquer outras formas de saber. Não importa tratar aqui da veracidade de suas premissas. Cumpre-nos constatar que ela é real para aquele que a toma como realidade sagrada. Muitas vezes, os estudos sobre a atuação política de grupos religiosos têm se pautado exclusivamente por questões políticas e sociais, quando não em termos de luta de classes, "sem, contudo, considerar a importância da religião, dos símbolos, mitos e ritos para a consecução do imaginário dessas comunidades em tais eventos". ${ }^{23}$ Nesse sentido, o anseio por salvação - salvação essa que pode ter sentidos variados - é a grande "bússola" que ordena os movimentos dos agentes religiosos no terreno da política. Cremos que essa chave é fundamental para a devida compreensão da relação entre fé e política no pensamento e na práxis da juventude católica brasileira durante os turbulentos anos 1960.

\section{Referências bibliográficas}

BELLAH, R. N. A nova consciência religiosa e a crise na modernidade. Religião e sociedade, v.13, n.2, p. 18-37, jul.1986.

CARDONNEL, T.; VAZ, H.; SOUZA, H. J. Cristianismo hoje. Rio de Janeiro: Editora Universitária, 1962.

${ }^{23}$ GOMES, A. M. A., O messianismo milenarista no Brasil e o mito do eterno retorno, p. 16. 
COX, H. The secular city: secularization and urbanization in theological perspective. New Jersey: Princeton University Press, 2013.

FINLEY, M. I. Usos e Abusos da História. São Paulo: Martins Fontes, 1989. FURTER, P. Dialética da esperança. Rio de Janeiro: Paz e Terra, 1974.

GOMES, A. M. A. O messianismo milenarista no Brasil e o mito do eterno retorno: limites e possibilidades de reflexão. Ciências da Religião - história e sociedade, v.6, n.2, p. 13-35, jul./dez. 2008.

KELLEY, D. R. Horizons of intelectual history: retrospecto, circumspect, prospect. Journal os the history of ideas, v.48, n. 1, p. 143-169, jan./mar. 1987.

KOSELLECK, R. “'Espaço de experiência' e 'Horizonte de expectativa': duas categorias históricas. In: KOSELLECK, R. Futuro passado: contribuição à semântica dos tempos históricos. Rio de Janeiro: Contraponto / Ed. PUC-Rio, 2006. p. 305-327.

KOSELLECK, R. Futuro passado: contribuição à semântica dos tempos históricos. Rio de Janeiro: Editora Contraponto / PUC-Rio, 2006.

LE GOFF, J. Documento/monumento. In: LE GOFF, J. História e memória. Campinas: editora UNICAMP, 2003, p. 525-541.

MANNHEIM, K. Ideologia e utopia. Rio de Janeiro: Zahar Editores, 1976.

RAMOS, D. V. A invenção do Caribe como contracultura e a revolução cubana. Revista Brasileira do Caribe, Vol.8, n.16, p. 459-471, jan./jun. 2008.

RIDENTI, M. S. Ação Popular: cristianismo e marxismo. In: REIS FILHO, D. A.; RIDENTI, M. (Orgs.) História do marxismo no Brasil: Partidos e organizações dos anos 20 aos 60. Campinas: editora UNICAMP, 2002, p. 213282. vol. 5 .

SIRINELLI, J. Os intelectuais. In: REMOND, R. Por uma história política. Rio de Janeiro: FGV, 2003, p. 231-269.

TILLICH, P. A era protestante. São Paulo: Ciências da Religião, 1992.

WEBER, M. Ensaios de sociologia. Rio de Janeiro: LTC, 1982. 
Wellington Teodoro da Silva Doutor em Ciências da Religião pela Universidade Federal de Juiz de Fora Docente do Programa de Pós-graduação em Ciências da Religião da Pontifícia Universidade Católica de Minas Gerais Belo Horizonte / MG - Brasil E-mail: wteodoro@pucminas.br

Daniel Rocha

Doutor em História pela Universidade Federal de Minas Gerais Docente do Curso de Teologia do Instituto Santo Tomás de Aquino Belo Horizonte / MG - Brasil E-mail: danielrochabh@yahoo.com.br

Recebido em: 23/01/18 Aprovado em: 19/07/18 